\title{
MENTAL HEALTH CARE SITUATION IN FAMILY HEALTH UNITS: PERCEPTIONS OF COMMUNITY HEALTH AGENTS
}

\author{
Jacqueline de Souza1, Francine Baltazar Assad², Sara Pinto Barbosa33, Heloisa França Badagnan ${ }^{4}$, Letícia \\ Yamawaka de Almeida ${ }^{5}$, Caroline Clapis Garla ${ }^{6}$
}

\begin{abstract}
${ }^{1}$ Ph.D. in Nursing. Lecturer in the Department of Psychiatric Nursing and Human Sciences of the Universidade de São Paulo (USP) at Ribeirão Preto College of Nursing. Ribeirão Preto, São Paulo, Brazil. Email: jacsouza2003@usp.br

2 Doctoral student of the Graduate Program in Psychiatric Nursing of the EERP/USP. Ribeirão Preto, São Paulo, Brazil. Email: franassad@hotmail.com

${ }^{3}$ Doctoral student of the Graduate Program in Psychiatric Nursing of the EERP/USP. Ribeirão Preto, São Paulo, Brazil. Email: saraenfer@yahoo.com.br

${ }^{4}$ Master's student of the Graduate Program in Psychiatric Nursing of the EERP/USP. Ribeirão Preto, São Paulo, Brazil. Email: heloisabadagnan@yahoo.com.br

${ }^{5}$ Nursing student of the EERP/USP. Ribeirão Preto, São Paulo, Brazil. E-mail: Leticia.almeida@usp.br

${ }^{6}$ Doctoral student of the Graduate Program in Community Health of the Ribeirão Preto Medical School of the USP. Ribeirão Preto, São Paulo, Brazil. Email: carolgarla@hotmail.com
\end{abstract}

\begin{abstract}
This was a qualitative, descriptive study, performed with 17 Community Health Agents. The aim was to analyze the perception of these professionals regarding the most frequent mental health cases in the region. Data was collected through observation of the region and two focus groups. We used the structuralist perspective for the analysis. The results showed that these professionals perceived mental health demands from an expanded concept of health, in which the resources fit together between the various sectors. They deal with difficulties, develop actions based on soft technologies and do not necessarily focus on the disease. It was concluded that these elements reinforce the power of the Community Health Agents as performers of mental health care practices and as an important link between the healthcare service and the community.
\end{abstract}

DESCRIPTORS: Primary health care. Family health. Mental health. Community health workers.

\section{SITUAÇÕES DE SAÚDE MENTAL NAS UNIDADES DE SAÚDE DA FAMÍLIA: PERCEPÇÃO DOS AGENTES COMUNITÁRIOS DE SAÚDE}

RESUMO: Trata-se de pesquisa qualitativa, descritiva, com 17 Agentes Comunitários de Saúde. O objetivo foi analisar a percepção destes profissionais quanto às situações de saúde mental mais frequentes no território. Os dados foram coletados utilizando observação do território e dois grupos focais. Para a análise utilizou-se a perspectiva estruturalista. Os resultados apontaram que estes profissionais percebem as demandas de saúde mental a partir de uma concepção ampliada de saúde, na qual os recursos se articulam intersetorialmente. Apesar de referirem dificuldades, desenvolviam ações calcadas em tecnologias leves e não, necessariamente, centradas na doença. Concluiu-se que estes aspectos reforçam a potência dos agentes comunitários de saúde como atores de práticas de saúde mental e importante elo entre o serviço de saúde e a comunidade.

DESCRITORES: Atenção primária à saúde. Saúde da família. Saúde mental. Agentes comunitários de saúde.

\section{SITUACIONES DE SALUD MENTAL EN LAS UNIDADES DE SALUD FAMILIAR: PERCEPCIÓN DE LOS AGENTES COMUNITARIOS DE SALUD}

RESUMEN: Se trata de una investigación descriptiva cualitativa, con 17 Agentes Comunitarios de Salud tuvo como objetivo analizar la percepción de estos profesionales con respecto a las situaciones de salud mental frecuente. Las tareas de los agentes comunitarios de salud son la identificación, prevención, promoción de la salud de las familias en el territorio. Se les considera actores importantes en la identificación de las necesidades de salud mental en la atención primaria. Para la recolección de datos se utilizó la observación y dos grupos focales. Para el análisis de los datos se utilizó la perspectiva estructuralista. El método utilizado fue la observación del territorio y grupos focales. Los resultados mostraron que estos profesionales tienen una visión amplia de las necesidades de salud mental y que los recursos de atención de salud se insertan en una propuesta intersectorial. Estos profesionales, aunque las dificultades que señalan, están desarrollando acciones basadas en las tecnología ligeras, y no necesariamente centrado en la enfermedad. Se concluye que estos aspectos refuerzan el poder de la agentes comunitarios de salud como actores de prácticas de salud mental y importante vínculo entre el servicio de salud y la comunidad.

DESCRIPTORES: Atención primaria de salud. Salud familiar. Salud mental. Agentes comunitarios de salud. 


\section{INTRODUCTION}

Various researchers have highlighted the large number of patients with undiagnosed mental health disorders, whether monitored or not. This occurs because many of these subjects seek health services due to somatic symptoms and professionals do not always relate such complaints to the mental health of these people, culminating in inefficiency and high rates of return to health services, as their problems are not resolved..$^{1-5}$

Accordingly, a study developed in the Netherlands indicated that $43 \%$ of patients with anxiety and depression did not receive any kind of care. In Canada, only $40 \%$ of people with mental disorders have access to specialist care. ${ }^{1,6}$ In a global context, $50 \%$ of people with anxiety and depression and at least one in three patients with schizophrenia receive no treatment. This percentage varies from 35 to $50 \%$ in developed countries and 76 to $85 \%$ in low or middle-income countries. ${ }^{7}$ This absence of monitoring leads to disabilities, culminating in human suffering and in economic losses to the countries. In addition, the countries with fewer mental health care resources are also those which have a more unequal distribution of such services. ${ }^{7}$

Brazil is among the two thirds of countries that have a mental health care policy which includes specific legislation for the protection of both the human and civil rights of people affected with mental health disorders. ${ }^{7}$ This policy meets an internationally created standard of community-based services to complement hospital care for resolving more actions at a lower cost. This recommendation is followed by only $52 \%$ of the low-income countries and by $97 \%$ of the highincome countries. ${ }^{7-8}$

In addition, Brazil is among the few lowand middle-income countries that have undertaken efforts to strengthen its primary health care (PHC), as well as its expert support (consultancy and support matrices), to improve the identification and subsequent treatment of people with mental health disorders. ${ }^{7,9-11}$ Brazil's supply of specialized human resources (psychiatric and nursing experts in the area) is similar to that of the United States, Canada, Australia, South Africa and some European countries: 25.1 to 600 per 100,000 inhabitants. $^{?}$

Some international researchers have highlighted the issue of access to mental health care as a crucial aspect because the existence of resources alone does not guarantee equal access to these services, i.e., necessity and access tend to vary inversely. ${ }^{6-7}$ Design of access includes both the geographic and spatial perspectives as the solution to the actions, which is crucial for the user's confidence in the assistance that can be provided by the health care service. ${ }^{1-6}$

In this light, the extension of mental health care to primary care consists of an access expansion strategy to increase the capacity of identification and resolution by the teams that confront mental health needs that are usually accompanied by other clinical demands, which likewise cannot be overlooked. In addition, attending to such needs in this setting decreases the stigma of mental illness, allowing for the detection of risk factors and of how the demand is contextualized in the area in which the user lives, contributing to more effective clinical and social outcomes. ${ }^{9-13}$

Mental health care in PHC in Brazil has gained momentum, especially in the Family Health Strategy (FHS) and the Community Health Agents Program (CHAP).${ }^{14}$ Community Health Agents (CHA) act together with other primary care professionals and their tasks involve actions of identification, prevention, health promotion and monitoring of the families in the region. ${ }^{15-16}$

The CHAs are important providers of the health actions for the population and one of the selection criteria is that they reside in the community in which they work, as the bond with the region facilitates the understanding of the social issues that permeate health situations and local diseases. They are recognized as healthcare professionals in accordance with law No. 10,507 of 2002 and, from 2006, have had working conditions in accordance with the Consolidation of Labor Laws (CLT). ${ }^{17-19}$

It is assumed that, in the exercise of their surveillance role and by linking with community services, these professionals are key players in the expansion of access and identification of mental health needs, through home visits and other actions that are performed in the region. These activities are performed in schools, in partnerships with community leaders and through contacts with religious organizations.

Thus, the development of studies that examine the participation of these professionals is essential for the identification and care of mental health needs undertaken by the FHS team. 
From this, the following question arises: what is the CHAs' perception regarding the most frequent mental health situations in the primary care context?

The aim of this study was to analyze the CHAs' perceptions regarding the most frequent mental health care situations in the region of the FHS teams.

\section{METHOD}

This was a qualitative, descriptive study, performed in areas assigned to five family health care teams in the Western Health Care region of Ribeirão Preto-SP, Brazil.

Data collection was conducted between May and November of 2011, in two stages: primarily through the observation technique and then through focus groups. Prior to the observation, there was an orientation session regarding the region, with seventeen $\mathrm{CHAs}$ and five nurses of the FHS, through eight meetings, in which these professionals provided a map of the region and their main considerations in relation to this. From these guidelines the script was written for observations with a focus on: meeting spaces; positive and negative aspects of the region; assistance and social protection mechanisms; nongovernmental organizations, and other health services in the region.

The fieldwork was conducted by five researchers, three being graduate students and two doctorate level professors. The observation period totaled forty-six hours. This data was analyzed by three of these researchers who had previously defined three categories, namely: Resources of the region, the strengths, and the weaknesses. This analysis allowed for the construction of a panorama of the Community Health Agents' work region and was used as the base for conducting the two subsequent focus groups.

The focus groups had an approximate duration of one hour and the main issues were: "what are the most common mental health situations and what resources does the region have to provide care in these situations?" To introduce these issues a presentation was made of the panorama previously constructed from the observations carried out in the region. Each group was mediated by two coordinators and featured two trained observers for the implementation of the focus group technique. The seventeen CHAs were divided into two groups, one with eight participants and the other with nine.

Audio from the group sessions was recorded and subsequently transcribed and read, aiming to understand the broad sense of its content. Next, re-readings were performed to identify groups of central themes based on the proposed study question. Finally, data categorization was performed, highlighting the thematic items and grouping the convergences.

The theoretical framework used for the analysis, was the concept of Structuralist Theory, based on work by Piaget and Levis-Strauss. ${ }^{19-20}$ This theory proposes that the total structure is formed by elements that are subject to certain "laws" of composition that characterize the system and give property sets different from the properties of each element.

The theory also assumes the relevance of the relationships between the elements that make up the structure. Thus, in this study, an analysis of the synchronization of the information provided was performed, i.e., of the relationships existing between the elements that underlie the statements of the subjects and the thematic structures that make up such elements. ${ }^{21-23}$

The process of interpretation and data analysis followed a structuralist research proto$\mathrm{col}^{21}$ namely: health practices in the region of the Family Health Care Units were determined as the observational field from which the elements related to the study aim described by the CHAs were highlighted.

In this step, each of the researchers carried out successive readings of the transcribed data, highlighting the topics and themes that were repeated, and gave their respective interpretations after considering the full content of the transcripts. After these individual readings, the researchers met in order to analyze the similarities and differences and to systematize the elements identified. From these elements, we sought to identify a relationship group between them and, from this, drafted the thematic structures. We then listed three thematic structures: most frequent mental health situations, strengths, and weaknesses and difficulties (Figure 1). The next step in the analysis was to construct a conscious model that could explain the data organization with a view to its interpretation. In this way, we devised tables aiming to illustrate the CHAs' statements for each thematic structure and their 
respective elements. Intuitive analysis was performed for the interpretation of results from the construction of the explanations based on relevant scientific literature.

Intuitive analysis from the structuralist perspective assumes the discovery of a structure underlying the information supplied by the subject. This structure was evident from the discussion and interpretation of the content, considering the observational field adopted, i.e. the linguistic material provided context to the realities experienced by the research subjects. ${ }^{21-23}$

The project was approved by the Research Ethics Committee of the Universidade de São Paulo, under Protocol CSE-FMRP-USP 426/2010, and the aspects provided for by resolution 466, of December 12, 2012, on research involving human subjects, adopted by the National Health Council were followed. The subjects, after agreeing to participate in the study, signed an Free and Informed Consent Form.

\section{RESULTS}

Seventeen CHAs participated in the focus groups and, of these participants, fourteen were female and three male, with ages ranging from 28 to 58 years. Fifteen of the subjects declared themselves to be white and two to be of mixed race. Regarding schooling, three were educated to degree level, thirteen had completed college, one had qualified from a technical college and one had completed only high school. Thirteen were married, two were in stable relationships, one was divorced and one provided no information.

Following the theoretical assumptions, the thematic structures were obtained from the synchronization between the constituent elements of the CHAs' statements, as shown in Figure 1. For each thematic structure the respective elements that were found are presented.

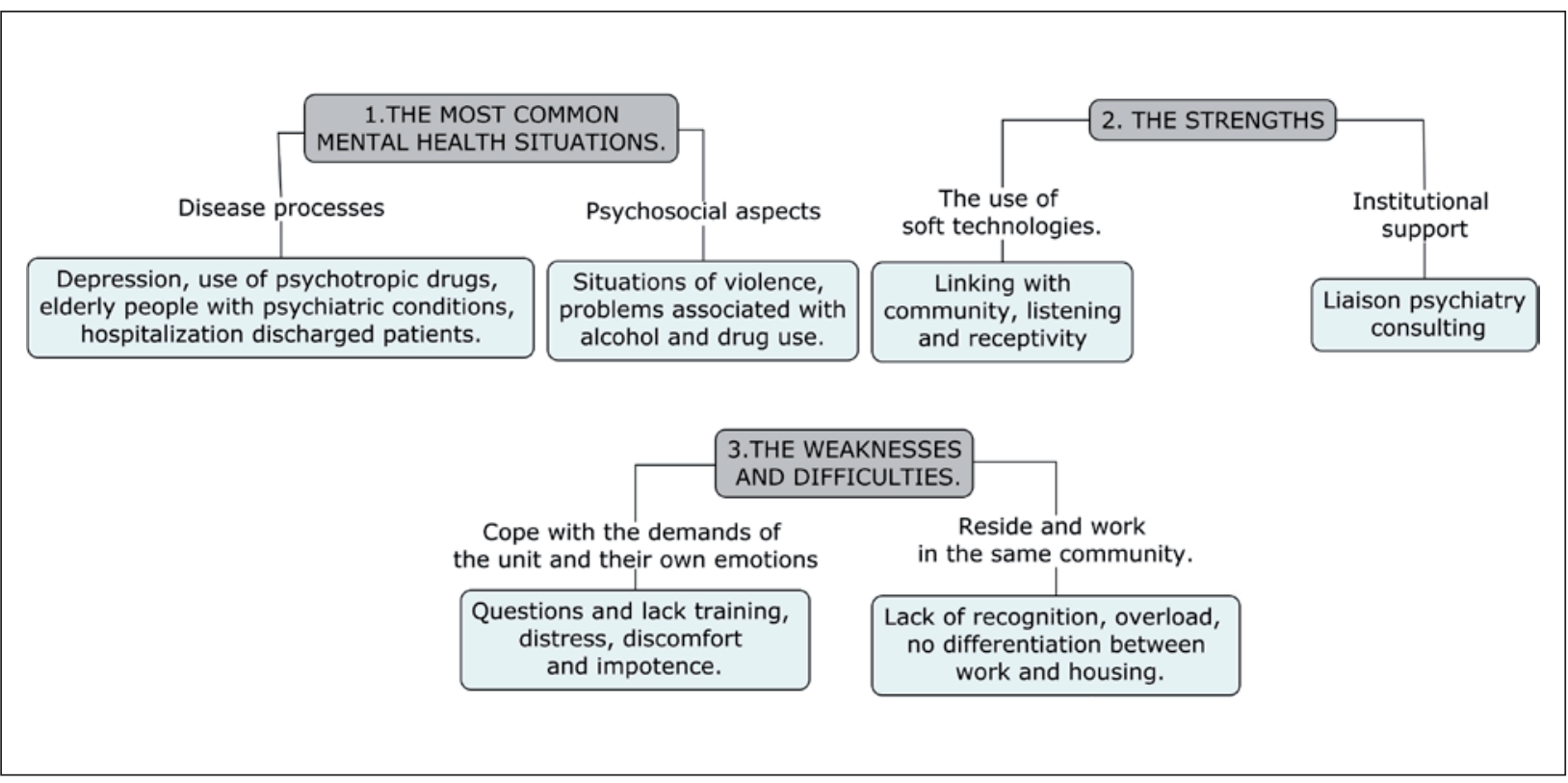

Figure 1 - The articulation between the thematic structures, the elements and the results. Ribeirão Preto - SP, 2011

In Table 1 some statements from the focus group corresponding to the elements of each thematic structure are presented. As can be seen, the elements were designed by the researchers as the parts that connect one idea to another in the content of the statements about the subject. 
Table 1 - Thematic structures and respective statements illustrating the listed elements. Ribeirão Preto - SP, 2011

\begin{tabular}{|c|c|}
\hline \multirow{2}{*}{ 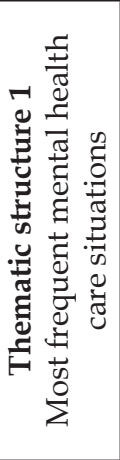 } & $\begin{array}{l}\text { A lot of people are taking sibutramine, fluoxetine. In almost every visit that you make, you find somebody in the } \\
\text { family taking it. } \\
\text { He's elderly with mental problems [...] he's elderly with dementia and stays home all day alone. } \\
\text { A patient who returned after [psychiatric] hospitalization [...] this person was hospitalized, did well and continued } \\
\text { making progress in the unit. }\end{array}$ \\
\hline & $\begin{array}{l}\text { me across a lot. The ghetto is a very complex area, there is prostitution, } \\
\text { Many alcoholics [...] we are familiar with these problems [of alcohol } \\
\text { tof this. }\end{array}$ \\
\hline \multirow{2}{*}{ 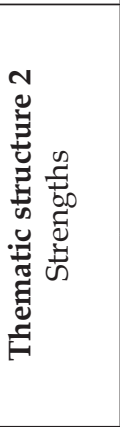 } & (a) \\
\hline & attend \\
\hline \multirow{2}{*}{ 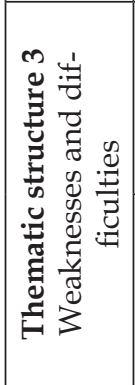 } & have \\
\hline & 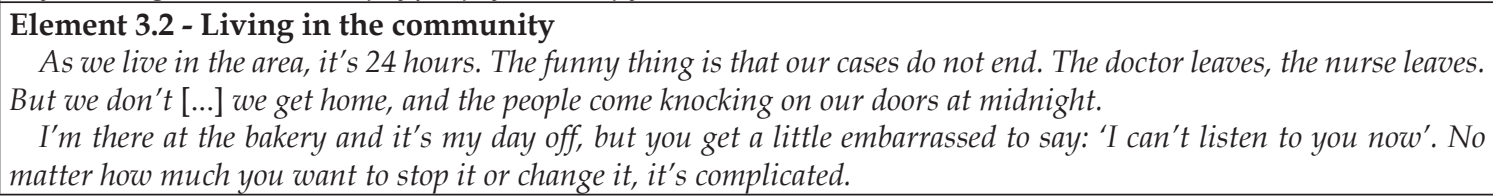 \\
\hline
\end{tabular}

\section{DISCUSSION}

From the questions about the CHAs' perceptions of mental health demands within the field of observation adopted (health practices in the region covered by the Family Health Care Units), the results indicated the following elements: processes of illness, psychosocial aspects, use of soft technologies, institutional support, demands and personal emotions, and the difficulties of living in the community in which the work is performed.

Thus, the relationships that connect these elements were discussed based on current mental health policies and on other studies of psychosocial rehabilitation and mental health in primary healthcare.

\section{Most frequent mental health care situations}

In recent years, teams have routinely dealt with mental health care demands. According to the Brazilian Ministry of Health, the majority of family health care teams (56\%) referred to acting on this demand, ${ }^{14}$ highlighting the need for the integration of mental health care within the PHC framework. ${ }^{24}$

Confirming this data, in this study the demand for mental health care in the Family Health Care Units was seen by the CHAs as being complex and diverse, with a considerable increase in the demand having been observed over recent years. The majority of the CHAs were able to identify mental health care needs, demonstrating sensitivity for the theme and showing consistency from the perspective of full-time care. ${ }^{25}$

The results corroborate the scientific literature that states that the most frequent mental health care demands in primary care are related to substance use and/ or abuse (alcohol, tobacco, psychotropic drugs and illicit substances) mental health disorders, patients already discharged 
from psychiatric hospitals, situations arising from violence, and situations arising from social exclusion. It is understood that the identification and monitoring of these situations, incorporated into the activities developed by primary health care teams, are fundamental steps for overcoming the need for pharmacological solutions and the psychiatric hospitalization models of mental health care. ${ }^{14,26}$

In addition to these demands, which are common in other studies, this study also addressed the mental health care demands of elderly people. The aging of the population culminates in different health care needs, including other forms of distressing situations or mental health disorders. ${ }^{27}$ This population already uses the routinely available general health services, therefore, it is important that different professionals are prepared to identify and appropriately conduct the care required for the different health needs of these individuals, including those related to mental health care.

\section{Strengths}

According to the accounts of the CHAs, one of the strength of meeting the mental health care demands was the use of "soft technologies", such as establishing bonds with the community, listening and being receptive. "Soft technologies" relate to establishing relationships in order to promote listening, acceptance, responsibility and a link to healthcare. ${ }^{28}$

The CHAs acknowledged that listening and conviviality enabled them a greater strengthening of the bond with the community when comparing their work to that of other healthcare professionals operating in the area. Thus, the CHAs were reaffirmed as important players in carrying out exchanges between general health knowledge and scientific medical knowledge, due to their position: acting as mediators between the community and other health professionals. ${ }^{29}$

The psychiatric consultancy and its connections were also highlighted as being a strength. Such consulting offers specialized back-up teams and strengthens the bonds between the team and users. ${ }^{14}$ The consultancy has the presence of a specialist in psychiatry in the unit or a general service to assist in specialist care, since the link theme refers to a closer bond between the expert and the team so that they can share in discussions and care..$^{30}$ According to the CHAs, this back-up allowed monitoring of some cases in the community and enhanced the ability of the FHS to attend the patients.

\section{Weaknesses and difficulties}

According to the CHAs, the identification of the demands was not seen as a difficulty, however, the major challenges were dealing with the demands and activating the inter-sectoral actions. The professionals faced situations of distress, discomfort, feelings of helplessness and doubts about the effectiveness of the mental health care, corroborating results from previous studies. $^{31}$

The respondents pointed out that by living in the same region users were presented with advantages and disadvantages; the strong bond put them in a good position of reference, however, did not allow the detachment necessary to maintain their privacy. This result corroborates the findings of a similar study developed with community health agents which highlighted the fact that living and working in the same neighborhood promoted the strengthening of various relationships that favor the bond, however, also exposed the private lives of these workers, because their social lives happen in the same space and everything that they do becomes common knowledge. ${ }^{32}$

The CHAs reported being unprepared and having a lack of training for mental health care. The ongoing training of the teams consists of a strategy that prioritizes the inclusion of mental health care at the basic care level, with it being crucial that this training is carried out as a continual work..$^{24}$ From this premise, it is necessary for the $\mathrm{CHAs}$ to be included in this training, which is seen as being of extreme importance within the primary health care team.

They also expressed a need for support due to the emotional burden of their everyday work. It is understood that life and work are inseparable, therefore, in the same way that the work may affect the lives of CHAs, the way that they manage their lives can affect the teams' working practices. The numerous situations experienced by the CHAs, including the environment of the regions, the users' ways of life and the social diversity, may resonate in the practices of care and acceptance, which demands accountability. ${ }^{32}$ Thus, it is believed that creating listening spaces could assist in maintaining the good mental health of the CHAs. 


\section{CONCLUSIONS}

From the results obtained, it can be considered that the CHAs participants of this study were able to identify the skills required in recognizing mental health care demands and also identify the resources that were available to them in the region. Mental health demands were understood by the majority of the CHAs as being composed of complex and diverse situations, such as drug use, violence and distress, which require inter-sectoral actions rather than actions only from healthcare services.

The CHAs were able to highlight some support mechanisms and also the strengths and weaknesses in the process of attending to mental health needs, although they stressed the need for greater support, such as continuing education and psychological support.

The incorporation of mental health into primary healthcare has been shown to be an important and current discussion in terms of support and research fields, as it concerns the articulation of knowledge and practices from the different sectors and workers involved in this process.

The main contribution of this study is to highlight that the perceptions of CHAs in relation to the identification of mental health needs arise from an expanded perspective of health that assumes inter-sectoral activities: they identified social situations and violence as mental health demands and highlighted different features, such as having the real ability to provide care, for example. In addition, this study shows that when referring to difficulties, these professionals were able to develop soft technologies that were based on action and not necessarily focused on the disease. These points reinforce the importance of the presence of the CHAs as a link between the health services and community and as actuaries of mental health care practices.

It should be noted that, although the $\mathrm{CHAs}$ are important allies for the identification of situations of vulnerability in the community for the processing of mental illness, it is necessary to pay attention to the mental health conditions of the workers whose daily lives are described in this study, as they are subject to emotional difficulties and suffering that result from the challenges of dealing with these demands within their own community.

\section{REFERENCES}

1. Verhaak PF, Prins MA, Spreeuwenberg P, Draisma S, Van Balkom TJ, Bensing JM, et al. Receiving treatment for common mental disorders. Gen Hosp Psychiatry. 2009; 31(1):46-55.

2. Ford JD, Trestman RL, Tennen H, Allen S. Relationship of anxiety, depression and alcohol use disorders to persistent high utilization and potentially problem under-utilization of primary medical care. Soc Sci Med. 2005 Oct; 61(7):1618-25.

3. Lin JMS, Brimmer DJ, Boneva RS, Jones JF, Reeves WC. Barriers to health care utilization in fatiguing illness: a population-based study in Georgia. BMC Health Serv Res. 2009 Jan 20; 9:13.

4. Cunningham PD, Connor PD, Manning JS, Stegbauer CC, Mynatt SL. Evaluation of mood disorder patients in a primary care practice: measures of affective temperament, mental health risk factors, and functional health in a retrospective, descriptive study of 35 patients. Prim Care Companion J Clin Psychiatry. 2009; 11(2):68-73.

5. Walters $\mathrm{P}$, Tylee A. Mood disorders in primary care. Psychiatry. 2006; 5(4):138-41.

6. Ngui AN, Vanasse A. Assessings spatial accessibility to mental health facilities in a urban environment. Spat Spatiotemporal Epidemiol. 2012 Sep; 3(3):195203.

7. Saxena S, Thornicroft G, Knapp M, Whiteford H. Resources for mental health: scarcity, inequaty, and inefficiency. Lancet. 2007 Sep 8; 370(9590):878-89.

8. Eaton J, McCay L, Semrau M, Chatterjee S, Baingana F, Araya R, et al. Scale up of services for mental health in low-income and middle-income countries. Lancet. 2011 Oct 29; 378(9802):1592-603.

9. Gonçalves DA, Fortes S, Campos M, Ballester D, Portugal FB, Tófoli LF, et al. Evaluation of a mental health training intervention for multidisciplinary teams in primary care in Brazil: a pre-and posttest study. Gen Hosp Psychiatry. 2013 May-Jun; 35(3):304-8.

10. Saunders K, Brain S, Ebmeier KP. Diagnosing and managing psychosis in primary care. Practitioner. 2011 May; 255(1740):17-20.

11. Thielke S, Vannoy S, Unützer J. Integrating mental health and primary care. Prim Care. 2007 Sep; 34(3):571-92.

12. Yeung A, Kung WW, Chung H, Rubenstein G, Roffi $\mathrm{P}$, Mischoulon D, et al. Integrating psychiatry and primary care improves acceptability to mental health services among Chinese Americans. Gen Hosp Psychiatry. 2004 Jul-Aug;26(4):256-60.

13. Dundon M, Dollar KM, Schon M, Lantinga LJ. Primary care-mental health integration colocated, collaborative care: an operations manual. [Internet]. Washington (DC): Center for Integrated Healthcare; 2011 [acesso 2013 jan 21]. Disponível em: http://www.mentalhealth.va.gov/coe/cihvisn2/Documents/Clinical/Operations_Policies_ Procedures/MH-IPC_CCC_Operations_Manual_ Version_2_1.pdf 
14. Ministério da Saúde (BR). Secretaria de Atenção à Saúde/DAPE. Saúde mental no SUS: acesso ao tratamento e mudança do modelo de atenção. Relatório de gestão 2003-2006. Brasília (DF): MS; 2007.

15. Ministério da Saúde (BR), Secretaria de Atenção à Saúde, Departamento de Atenção Básica. O trabalho do Agente Comunitário de Saúde. Brasília (DF): MS; 2009.

16. Malfitano APS. Atrás da porta que se abre: demandas sociais e o Programa de Saúde da Família. $2^{\mathrm{a}}$ ed. Holambra (SP): Setembro; 2007.

17. Brasil. Lei n. 11.350 de 05 de Outubro de 2006: dispõe sobre o aproveitamento de pessoal amparado pelo parágrafo único do art. 20 da Emenda Constitucional no. 51 , de 14 de fevereiro de 2006, e dá outras providências. Diário Oficial da República Federativa do Brasil, 09 Jun 2006.

18. Barros DF, Barbieri AR, Ivo ML, Silva MG. O contexto da formação dos Agentes Comunitários de Saúde no Brasil. Texto Contexto Enferm. 2010. 19(1):78-84.

19. Piaget J. O estruturalismo. São Paulo (SP): Difel; 1979. 128p.

20. Lévi-Strauss, C. Antropologia estrutural. Rio de Janeiro: Tempo Brasileiro; 1970. 300p.

21. Thiry-Cherques HR. Métodos estruturalistas: pesquisa em ciências da gestão. São Paulo (SP): Editora Atlas, 2008.

22. Lepargneur H. Introdução aos estruturalismos. São Paulo (SP): Editora Herder, 1972.

23. Lepschy GC. A linguística estrutural. São Paulo (SP): Editora Perspectiva, 1975.

24. Ministério da Saúde (BR), Secretaria de atenção à saúde. Saúde mental e atenção básica: o vínculo e o diálogo necessários. Brasília (DF): MS; 2003.

25. Harada OL, Soares MH. The perception of the Community Health Agent to identify depression. SMAD Rev Eletr Saúde Mental Álcool Drog [online]. 2010[acesso em 2009 jun 22]; 6(2):315-336. Disponível em: http:/ / pepsic.bvsalud.org/pdf/smad/v6n2/6.pdf

26. McCrae N, Banerjee S. The challenge of evaluating mental health services for older people. Int J Geriatr Psychiatry. 2011 Jun; 26(6):551-7.

27. Caçapava JR, Colvero LA, Martines WRV, Machado $\mathrm{AL}$, Aranha e Silva AL, Vargas D, Oliveira MAF, et al. Work in primary health care: a comprehensive mental healthcare. Rev Esc Enferm USP [online]. 2009 [acesso 2012 Set 20]; 43(spe2):1256-1260. Disponível em: http://www.scielo.br/scielo.php?script=sci_ arttext\&pid=S0080-62342009000600019\&lng=en

28. Schraiber LB, Mota A, Novaes HMD. Tecnologias em saúde. Dicionário da educação profissional em saúde. Rio de Janeiro: Fiocruz [online]. 2009. [acesso 2012 Set 20]; Disponível em: http://www.epsjv. fiocruz.br/dicionario/verbetes/tecsau.html

29. Ferreira VSCF, Andrade CS, Franco TB, Merhy EE. Community Health Agents' work process and restructuring. Cad Saúde Pública [online]. 2009 [acesso 2012 Set 20]; 25(4):898-906. Disponível em: http://www.scielo.br/pdf/csp/v25n4/21.pdf

30. Grover S. State of Consultation-Liaison Psychiatry in India: current status and vision for future. Indian J Psychiatry [online]. 2011 [acesso 2014 Jan 15]; 53(3):202-13. Disponível em: http://www.ncbi.nlm.nih.gov/pmc/articles/ PMC3221175/?report=classic

31. Chiaverini DH, organizador. Guia prático de matriciamento em saúde mental. Brasília (DF)----: Ministério da Saúde/Centro de Estudo e Pesquisa em Saúde Coletiva; 2011.

32. Jardim TA, Lancman S. Subjective aspects of living and working with in the same community: the realities experienced by community health care agents. Interface (Botucatu). [online]. 2009 [acesso 2012 Set 20]; 13(28):123-35. Disponível em: http://www.scielo.br/scielo.php?script=sci arttext\&pid=S1414-32832009000100011 